\title{
I Ogólnopolska Konferencja Naukowa - „Z dziejów zdrowia publicznego" (Lódź, 2 -3 grudnia 2004)
}

W dniach od 2 do 3 grudnia 2004 roku w Łodzi odbyła się I Ogólnopolska Konferencja Naukowa pt. „Z dziejów zdrowia publicznego".

Organizatorem konferencji były: Szkoła Zdrowia Publicznego Instytutu Medycyny Pracy im. prof. J. Nofera w Łodzi, Katedra Etnologii i Antropologii Kulturowej Uniwersytetu Wrocławskiego oraz Polskie Towarzystwo Zdrowia Publicznego. Uczestnicy reprezentowali ośrodki naukowe z Bydgoszczy, Częstochowy, Gliwic, Krakowa, Lublina, Łodzi, Opola, Piotrkowa Trybunalskiego, Poznania, Słupska, Szczecina, Wrocławia oraz Warszawy.

Celem konferencji było zainicjowanie wielodyscyplinarnego spojrzenia na zdrowie ludów (narodów) i wybranych populacji z perspektywy dziejów, od czasów najdawniejszych do współczesnych, tj. do okresu po II wojnie światowej.

Wystapienia zostały zaprezentowane w sześciu sesjach tematycznych: „Obrazy lekarzy, pacjentów oraz stanu ich zdrowia w literaturze pięknej”, „Sytuacja demograficzna w Europie i stan zdrowia arystokracji polskiej w dobie nowożytnej”, „Instytucjonalna i społeczna troska o zdrowie publiczne w Polsce w okresie zaborów”, ,Zdrowie publiczne w Polsce w okresie II Rzeczypospolitej”, „Kwestie zdrowotne w Europie Wschodniej” oraz "Środowiskowe i organizacyjne aspekty zdrowia publicznego w Polsce po II Wojnie Światowej".

Pierwszy dzień konferencji poświęcony był referatom z trzech pierwszych sesji tematycznych. Obradom pierwszej sesji przewodniczyła prof. dr hab. Bożena Plonka Syroka (Uniwersytet Wrocławski). W pierwszym referacie Anna Lasek (UAM) przedstawiła obraz lekarza w najwcześniejszych dzielach literatury greckiej. Autorka podkreślała w nim, że już w eposach Homera, lekarze byli szanowani i doceniani, gdyż nie tylko ,potrafili dobywać z ciał strzały i leki stosować”, ale również leczyć niedomagania w racjonalny sposób: chirurgiczny (oczyszczanie, opatrywanie ran), farmaceutyczny (stosowanie ziół), czy też za pomoca diety. Choroby, których przyczyny nie były jasne starożytnym medykom, jako efekt działania demonów lub kary zesłanej przez rozgniewanych bogów, starano się leczyć za pomoca czarów, magicznych zaklęć i oczyszczeń. Powyższy wątek kontynuowała w swoim referacie Danuta Szaroszyk Socha (UAM). Autorka próbowała przedstawić zagadnienia medyczne dotyczące lekarzy i pacjentów na przykładzie epigramatu greckiego. Podkreślała, że w epigramatach informowano o przyczynie zgonu, o chorobie, jej przebiegu czy próbach jej zapobiegania, dziękowano za uzdrowienie, wyjaśniano przyczyny wdzięczności. W utworach poswięconych lekarzom, obok kpin z lekarzy konowałów, pojawiały się także teksty świadczące o szacunku, jakim medycyna cieszyła się w starożytności oraz o erudycji i profesjonalizmie antycznych przedstawicieli tego zawodu. Kolejny referat zostal wygłoszony przez Agnieszkę Tetrycz-Puzio (Pomorska Akademia Pedagogiczna, Słupsk). Autorka omówiła w nim stan zdrowia ludności ziem polskich od XI do XIII wieku, na podstawie zachowanych średniowiecznych źródeł narracyjnych. Autorka podkreślała $\mathrm{w}$ nim, że jakkolwiek podstawa źródłowa w odniesieniu do omawianego okresu jest niezwykle skąpa, co znacznie ogranicza kompleksowe przedstawienie i ocenę stanu zdrowia ludności ziem polskich, to zdecydowanie więcej informacji dostarczają średniowieczne źródła o problemach zdrowotnych przedstawicieli elit czy dynastii. Dużo mówią już same przydomki książat, np. Bolesław Krzywousty, Mieszko I Plątonogi, Władysław Laskonogi, Henryk V Brzuchaty, Konrad II Garbaty. Autorka podkreslała również, iż ze źródel wynika, że przedstawiciele dynastii piastowskiej z dwóch tendencji charakterystycznych dla średniowiecza wstrzemięźliwości, która wzmacnia oczyszczając oraz obfitości, która wzmacnia wypełniając ulegali zdecydowanie tej drugiej tendencji.

Następnie głos zabrała Zinajda Pakholok ( Wołyński Państwowy Uniwersytet), która zaprezentowała słuchaczom znaczenie medycyny ludowej w twórczości literackiej Mikołaja Kruszewskiego. 
Pierwsza sesję zakończyła swoim wystąpieniem Krystyna Pietrych (Uniwersytet Lódzki). Podjęła ona próbę ukazania obrazów choroby i cierpienia we współczesnej poezji polskiej. Posłużyła się w tym celu twórczością: Aleksandra Wata, Mirona Białoszewskiego, Zbigniewa Herberta oraz Stanisława Barańczaka.

W ramach drugiej sesji znalazło się sześć referatów. Obradom tej sesji przewodniczył prof. dr hab. Tadeusz Srogosz ( Częstochowa). Pierwszy z referentów, Edyta Wolter (SGGW, Warszawa) przedstawiła uczestnikom ewolucje przesłanek intrapersonalnej homeostazy duchowej poczawszy od średniowiecza, kiedy zgodnie z paradygmatem symboliki religijnej, Bóg jest źródłem, a człowiek wszczepiony w Boże Misterium życia, poprzez ideę renesansowego humanizmu antropocentrycznego i barokowego humanizmu teocentrycznego, aż do epoki oświecenia ludzkiego rozumu. Andrzej Michalski (Pomorska Akademia Pedagogiczna, Słupsk) omówił z kolei zagrożenia mające wpływ na procesy demograficzne. Jednym $\mathrm{z}$ takich zagrożeń, jak podkreślał autor, była jakość i ilość dostępnej żywności oraz wybuchy epidemii. Kolejny referent, Anna Łysiak-Łatkowska (PAP, Słupsk) skupiła się na zdrowiu polskiej arystokracji w dobie Oświecenia. Zamierzeniem autorki było zaprezentowanie wizerunków bardziej i mniej znanych polskich arystokratek i szlachcianek oraz metod maskowania u nich śladów ospy, choroby, która pozostawiając trwałe blizny i deformując ciało uniemożliwiała realizację zamierzonych celów, silne przeżycia psychiczne i rezygnację z przyjemności światowego życia. Iwona Wołyniec ( Częstochowa) omówiła koncepcję Stefana Garczyńskiego, autora „Anatomii Rzeczypospolitej Polskiej" - dotycząca zależności zdrowia ludności Rzeczpospolitej w pierwszej połowie XVIII wieku od warunków bytu. Następnie głos zabrała Katarzyna Krawczyk (Częstochowa), która zaprezentowała słuchaczom działalność komisji boni ordinis (dobrego porządku) wobec kwestii sanitarno-zdrowotnych miast królewskich w XVIII wieku. Druga sesję zakończył swoim wystapieniem Jan Nosko (Szkoła Zdrowia Publicznego, Eódź). Podjał on próbę ukazania dwóch tematów. Jeden dotyczył wychowania zdrowotnego młodego księcia Adama Jerzego Czartoryskiego, a drugi natomiast omawiał zalecenia higieniczne księcia Michała Hieronima Radziwiłła dotyczace obiektów pałacowych w Nieborowie, czystości urządzeń, jak i osób z nich korzystających. Autor posłużył się w tym celu dwoma oryginalnymi dokumentami z 1783r., z bogatej, liczącej 6 tysięcy tomów biblioteki Muzeum Narodowego w Nieborowie i zawierającej najważniejsze dzieła medyczne XVIII wieku opublikowane w języku lacińskim, niemieckim, francuskim, włoskim i angielskim.

W ramach trzeciej sesji znalazło się siedem referatów. Obradom sesji przewodniczył doc. dr hab. Jaromir Jeszke (PAN, Warszawa). Wystapienia rozpoczał Tadeusz Srogosz (Częstochowa), który zaprezentował słuchaczom dylematy zorganizowania Kolegium Medycznego w I Rzeczpospolitej. Kolejny referent, Marcin Winiarz (Uniwersytet Wrocławski), skupił się na ochronie zdrowia mieszkańców rozwijających się ośrodków miejskich w Królestwie Polskim w latach 1815 - 1863. Z kolei Tomasz Tokarek (Uniwersytet Wrocławski) mówił o opiece lekarskiej nad pensjonariuszami Ogólnego Schronienia Ubogich w latach 1816-1914, jako formie działalności charytatywnej w Krakowie. Następne wystapienie, autorstwa Ewy Kałamackiej, dotyczyło wpływu aktywności ruchowej na zdrowie. Podkreślano w nim, że zależność tę kojarzono w różnych epokach na różnej zasadzie i z różna siła. Autorka starała się wykazać, że przyczynkiem do rozwoju edukacji zdrowotnej było lenistwo ruchowe, któremu zaczęli ulegać Polacy w XIX wieku. Poprzez popularyzowanie wiedzy o zdrowiu lekarze podkreślali, że ruch jest niezbędny dla zdrowia. Jednak do XIX wieku jedynym środkiem informacji i działalności w zakresie promocji zdrowia było słowo drukowane. Dopiero w XIX wieku pojawiły się instytucje służące realnemu doskonaleniu zdrowia. W następnym referacie autorstwa Wlodzimierza Kaczorowskiego i Antoniego Maziarza (Uniwersytet Opolski), zaprezentowano słuchaczom udział żeńskich zgromadzeń zakonnych w opiece zdrowotnej na Ślasku w drugiej połowie XIX wieku. Podkreślono w nim i zaprezentowano również sytuację zdrowotną na Śląsku, aktywność Kościoła katolickiego w zakresie opieki zdrowotnej i społecznej oraz działalność medyczna sióstr w opinii społecznej. Walentyna Krystyna Korpalska (Akademia Medyczna, Bydgoszcz) mówiła o wpływie ustawodawstwa niemieckiego na rozwój instytucji ochrony zdrowia publicznego na ziemiach polskich pod zaborem pruskim. Autorka wystapienia podkreślała, że pruskie ustawodawstwo medyczne 
$z$ drugiej połowy XIX wieku było pionierskie $w$ stosunku do podobnych rozwiązań w zaborze rosyjskim i austriackim, jednakże dyrektywy i restrykcyjny charakter systemu opieki zdrowotnej, w specyficznych warunkach, pod obcym panowaniem był odbierany z niezrozumieniem i nieraz bojkotowany. Trzecią sesję zakończył swoim wystapieniem Marek Dutkiewicz (Akademia Świętokrzyska, Filia Piotrków Trybunalski). Podjął on próbę ukazania krakowskich placówek medycznych Legionów Polskich w latach 1914-1917. Autor wystąienia przedstawił słuchaczom nie tylko dzialalność krakowskich szpitali wojskowych, ośrodka leczenia, rehabilitacji i nauki dla inwalidów legionowych, ale także dzialalność Ambulatorium Dentystycznego Legionów Polskich zorganizowanego i prowadzonego społecznie przez stomatologów pod kierunkiem prof.Wincentego Łebkowskiego oraz działalność laboratorium prof. Odo Bujwida zaopatrującego bezpłatnie formacje legionowe w szczepionki.

Kolejne wystapienia miały miejsce drugiego dnia obrad. Sesji czwartej współprzewodniczyli: prof. dr hab. med.Tadeusz Brzeziński (Pomorska Akademia Medyczna) oraz prof. dr hab. Andrzej Felchner (Akademia Świętokrzyska, Filia Piotrków Trybunalski). Sesję rozpoczęla swoim wystapieniem Małgorzata Olszewska (Akademia Świętokrzyska, Filia Piotrków Trybunalski). Przedstawiła ona uczestnikom kwestie zdrowotne w szkolnictwie II Rzeczypospolitej. Szczególną uwagę skupiła autorka na sytuacji zdrowotnej szkolnictwa wołyńskiego, na Kresach oraz Polski centralnej w okresie międzywojennym. Sebastian Kulesza ( Pomorska Akademia Medyczna, Szczecin) z kolei omówił zagadnienia wychowania seksualnego w szkolnictwie II Rzeczypospolitej. Autor wystapienia starał się wykazać, że podejście do tego zagadnienia było zróżnicowane. Kwestii wychowania seksualnego nie normowały dostatecznie nieliczne i ogólnikowe zarządzenia administracyjne wydawane przez Ministerstwo Wyznań Religijnych i Oświecenia Publicznego. Miejsce na te zagadnienia pozostawiano jedynie w ramach zajęć $z$ biologii, w wychowaniu moralnym i religijnym oraz w zakresie działalności lekarzy szkolnych. Istotne znaczenie dla realizacji wychowania seksualnego miała niewatpliwie postawa Kościoła, a zwłaszcza encyklika papieża Piusa XI, która krytykując te zagadnienia wpłynęła na zahamowanie realizacji tej kwestii. Małgorzata Posłuszna (Akademia Medyczna, Poznań) skupila się na stanie sanitarno-higienicznym wsi polskiej w okresie II Rzeczypospolitej. Autorka wystapienia podkreśliła w nim, że wieś polska była bardzo zaniedbana. Wiele do życzenia pozostawiał nie tylko stan mieszkań, ich usytuowanie czy warunki otoczenia, które w poważnym stopniu oddziaływały na zdrowie ludności wiejskiej, ale istotne znaczenia mial też stan urządzeń sanitarnych oraz zaopatrzenie ludności w zdrowa wodę. Marek Sioma (UMCS, Lublin) natomiast zaprezentował administracyjne aspekty działalności prozdrowotnej Ministra Spraw Wewnętrznych Sławoja Składkowskiego. Autor położył nacisk na ukazanie wysiłków Składkowskiego na rzecz podniesienia higieny społeczeństwa poprzez pryzmat jego osobistych i urzędowych działań w tym kierunku. Następnie głos zabrał Robert Litwiński (UMCS, Lublin), który starał się wykazać jak duży wpływ na zdrowotność policjantów w okresie międzywojennym miały warunki panujące w miejscu pracy. Kolejne wystąpienie, autorstwa Michała Musielaka i Doroty Hędzelek (Akademia Medyczna, Poznań), dotyczyło bardzo ciekawych poglądów polskich i amerykańskich eugeników na temat „osób małowartościowych”. Podkreślono w nim, że według eugeników amerykańskich celem polityki zdrowotnej państwa nie powinna być ochrona ludzi przed złym środowiskiem, ale przed gwałtownym przyrostem osób eugenicznie małowartościowych, gdyż pewne choroby społeczne przekazywane są z pokolenia na pokolenie. Z kolei eugenicy polscy wysunęli tezę, że I wojna światowa doprowadziła nie tylko do nadmiernego spadku liczby ludności, ale przede wszystkim spowodowała eliminację i degeneracje "najwartościowszego elementu polskiego". Janusz Kłapeć (UMCS, Lublin) przedstawil charakterystykę stanu sanitarnego miasta Lublina oraz omówił rozwój placówek służby zdrowia w okresie międzywojennym. Przedstawiona została baza szpitalna jaka dysponowało miasto wraz z krótka charakterystyka poszczególnych placówek, zakres i charakter lecznictwa samorzadowego i prywatnego działajacego w Lublinie oraz związanych z nim ludzi. Autor zaprezentował także krótki rys historyczny dzialalności Pogotowia Ratunkowego oraz PCK. Sesję czwarta zakończył swoim wystapieniem Zdzisław Jezierski (Uniwersytet Medyczny, Łódź). Podjał on próbę ukazania problematyki zdrowia publicznego w polityce hitlerowskich Niemiec na terenie okupowanej Polski w latach 1939-1945. 
W ramach sesji piatej wygłoszono trzy referaty, a obradom przewodniczył prof. dr hab. Adam Paluch (Uniwersytet Wrocławski). Jako pierwszy referent wystapił Paweł Olszewski (Akademia Świętokrzyska, Filia Piotrków Trybunalski). Przedstawił on słuchaczom stosunkowo mało znaną kwestię pomocy dla ludności ormiańskiej po I wojnie światowej. Efektem tych działań - jak podkreślał referent - było uratowanie od śmierci tysięcy osób. Wystapienie Hanny Havshykowej (UMCS, Lublin) dotyczyło działalności kościoła Adwentystów Dnia Siódmego na Ukrainie na rzecz zdrowia. Mówczyni podkreślała w nim, że w działaniach podejmowanych na rzecz zdrowia kościół adwentystów wykorzystuje profilaktyczne programy zdrowotne, organizuje wystawy, prowadzi kilkudniowe zajęcia terapeutyczne, naucza podstaw zdrowego stylu życia. Sesję tę zamykała swoim wystąpieniem Danuta Penkala Gawęcka (UAM). Przedstawiła ona referat nt.: „Promocja zdrowia czy nowej religii. Popularyzacja systemu naturalnego uzdrawiania Porfirego Iwanowa w Kazachstanie”. Autorka podkreślała w nim, że tzw. „ruch iwanowców” propaguje system naturalnego uzdrawiania, polegajacy na hartowaniu ciała poprzez oblewanie ciała zimna woda, przestrzeganie postów oraz doskonalenie ducha. Coraz częściej praktyki ,naturalnego uzdrawiania" wprowadzane sa w przedszkolach i szkołach oraz w centrach rehabilitacji dzieci.

Obradom ostatniej sesji przewodniczyli: prof. dr hab. Stanislaw Tarkowski (Eódź) oraz dr Włodzimierz Piatkowski (UMCS, Lublin). Otworzył ja swoim wystapieniem Zbigniew Jastrzębowski (Politechnika, Częstochowa). Jego referat dotyczył kwestii zdrowia publicznego w doktrynie welfare state. Dla zobrazowania problemu autor postużył się dokumentami organizacji międzynarodowych (WHO) oraz Unii Europejskiej i Rady Europy. Elżbieta Więckowska (Akademia Medyczna, Wrocław) z kolei omówiła postępowanie z chorymi na gruźlicę w pierwszych latach po zakończeniu II wojny światowej. Autorka szczególna uwage zwróciła na kompetencje Naczelnego Nadzwyczajnego Komisariatu do Walki z Epidemiami, którego działalność w istotny sposób przyczyniła się do stopniowego wygaszania ognisk gruźlicy w społeczeństwie. Ryszard Szozda (Gliwice), kolejny mówca tej sesji, przedstawił referat pt. „Znawca i biegły sadowy z dziedziny medycyny sądowej na ziemiach polskich". Autor stwierdził, że analiza przepisów dotyczących problematyki biegłych sądowych prowadzi do wniosku, iż niestety do tej pory nie zdołano uwzględnić wszystkich koniecznych uwarunkowań w zakresie czynności biegłych sądowych. Następnie glos zabrała ponownie Elżbieta Więckowska, która wygłosiła referat pt. Monar jako organizacja pozarządowa. Autorka podjęła próbę ukazania działań profilaktyczno-edukacyjnych w okresie 25 lat istnienia Monaru. Małgorzata Hofman (UAM, Poznań) z kolei omówiła zależność zdrowia od warunków pracy i wykonywanej pracy od zdrowia na przykładzie pedagogów z miasta Kościana w województwie wielkopolskim. Agnieszka Owsianka skupiła się na organizacji i działalności Wydziału Zdrowia i Opieki Społecznej Urzędu Wojewódzkiego w Piotrkowie Trybunalskim w latach 1975-1998. Autorka omówiła zadania i cele Wydziału, przeanalizowała działania dążace do podwyższenia poziomu zdrowia wśród ludności województwa oraz zaprezentowała działania uwzględniajace potrzeby społeczeństwa. Małgorzata Leźnicka (Bydgoszcz) z kolei zaprezentowała w swoim wystapieniu województwo kujawsko-pomorskie jako województwo promujące zdrowie. Autorka przedstawiła uczestnikom program pod nazwa „Województwo Promujące Zdrowie”, który realizuje województwo oraz etapy dzialań z orientacja na zasoby, potrzeby, zagrożenia środowiskowe, indywidualne i rodzinne oraz cele lokalnej polityki zdrowotnej. Wiesław Ślósarz ( Uniwersytet Wrocławski) omówil ewolucje postaw w zakresie zdrowia seksualnego. Referent podkreślał, że wynika ona glównie z postępu wiedzy, upowszechnienia edukacji seksualnej i przemian obyczajowych. Sesję zakończyło wystapienie Jadwigi Rakowskiej, która zaprezentowała słuchaczom referat pt. „Relacja człowiek - środowisko naturalne w kontekście historycznym".

Konferencję zakończono krótkim podsumowaniem i zapowiedzią, że przedstawione referaty ukażą się w druku. 